\title{
Being a P.E. Does Make a Difference
}

\section{Terry Clausing}

I graduated from the University of Cincinnati with a B.S. in Mechanical Engineering in 1978. When I graduated, my father, Lloyd N. Clausing (1926-2007), shared with me some advice he was given when he graduated as a mechanical engineer back in 1950. $\mathrm{He}$, along with thousands of others, had served in World War II and enlisted right out of high school. After the war and upon his graduation from college, one of his professors had dismissed their class saying "all you young unmarried guys can leave. The rest of you need to stay and hear my advice." The wise professor proceeded to share his bits of knowledge, and the most memorable to me was that it is your personal responsibility to take out the garbage each week, and to realize that every item that you are throwing away is an item for which you paid your hard-earned money. Dad also shared his personal wisdom, saying "get your P.E. license. It will open doors and give you opportunities that others will never have."

My first job out of college was as an engineer for the U.S. Shoe Company. I learned that there is a tremendous amount of engineering in the manufacturing of women's shoes and the machinery that produce them. As a young engineer in the shoe industry, and at that time an E.I.T. (Professional Engineer-in-Training), not many people had any idea what an E.I.T. was ... except when having discussions with the major equipment suppliers. A few years later when I interviewed for a job with the National Distillers and Chemical Company (NDCC), my E.I.T. was a very strong point in my favor. The vice president of NDCC was a P.E. and my E.I.T. was what opened the door and got me the interview.

After seven years of experience and another job change, I took and passed the P.E. exam. I moved from manufacturing into technical sales, selling instrumentation such as mass flow meters, vacuum gauges, signal conditioners, infrared temperature sensors, and more. I would often introduce myself as the world's worst salesman; if you don't have a problem, you really do not need the instruments that I was selling. I never sold equipment-I only sold solutions to problems. My customers were primarily other engineers, typically manufacturing engineers, plant engineers, laboratory managers, and scientists. I learned that "P.E." on my business card often helped establish professional credibility; I was not simply another sales person. It was not about selling equipment, it was all about helping to solve their problems.

My career has taken several twists and turns. My industrial sales experience with infrared temperature sensors led me to infrared cameras, which in turn led me to building science and the study of energy efficiency in buildings. I have learned again the value of the P.E. as it clearly differentiates one among the masses. While people are often confused by marketing hype, most people genuinely desire solutions to their problems. I think of it as the "good engineer's seal of approval." I take the Engineer's Creed seriously:

"As a Professional Engineer, I dedicate my professional knowledge and skill to the advancement and betterment of human welfare. I pledge:

To give the utmost of performance;

To participate in none but honest enterprise;

To live and work according to the laws of man and the highest standards of professional conduct;

To place service before profit, the honor and standing of the profession before personal advantage, and the public welfare above all other considerations.

In humility and with need for Divine Guidance, I make this pledge."

[Adopted by National Society of Professional Engineers, June 1954]

Dad was right. It is our duty to take out the garbage, and being a P.E. does make a difference.

L. Terry Clausing is president of Drysdale \& Associates, Inc., P.O. Box 44055, Cincinnati, OH 45244; (513) 739-2317. 